\title{
Puberty of Charolais heifers in relation to growth rate. 1. Phenotypic variability
}

\author{
Marie-Madeleine Mialon ${ }^{\mathrm{a} *}$, Gilles Renand $^{\mathrm{a}}$, Daniel Krauss ${ }^{\mathrm{b}}$, \\ François Ménissier ${ }^{\mathrm{a}}$ \\ a Inra, Station de génétique quantitative et appliquée, 78352 Jouy-en-Josas cedex, France \\ ${ }^{\mathrm{b}}$ Inra, Domaine expérimental de Galle, 18520 Avord, France
}

(Received 18 December 1998; accepted 30 July 1999)

\begin{abstract}
In an experimental Charolais herd of 351 heifers, the establishment of puberty was described through 2 monthly blood progesterone assays at 10-day intervals and daily oestrus observations between 10 and 20 months of age. At 15 months of age, $72 \%$ of the heifers exhibited an oestrous behaviour, $56 \%$ a positive progesterone assay and $53 \%$ the two events. The mean age and weight at the first oestrus were $426 \pm 42$ days and $406 \pm 38 \mathrm{~kg}$ (respectively, $445 \pm 43$ days and $418 \pm 36 \mathrm{~kg}$ at the first positive progesterone test). Environmental factors influencing age at puberty were identified: year and period of birth, age of dam and twinning birth. Some of these factors act through an effect on the growth rate of the heifer. When data were adjusted for these factors, a moderate favourable phenotypic relationship still existed between growth rate and puberty-related traits. (C) Elsevier / Inra)

puberty / beef cattle / oestrus / progesterone / growth

Résumé - Âge à la puberté chez la génisse Charolaise en relation avec la croissance. 1. Variabilité phénotypique. Dans un troupeau expérimental de 351 génisses Charolaises, l'établissement e la puberté a été décrit grâce à deux dosages mensuels réalisés à $10 \mathrm{j}$ d'intervalle, de progestérone plasmatique et à la détection biquotidienne des comportements de chaleurs entre les âges de 10 et 20 mois. À 15 mois, $72 \%$ des génisses ont manifesté des chaleurs, $56 \%$ ont eu un dosage positif de progestérone et $53 \%$ ont présenté les deux événements. En moyenne, ces génisses manifestent leurs premières chaleurs à l'âge de $426 \pm 42 \mathrm{j}$ à un poids de $406 \pm 38 \mathrm{~kg}$ et leur première sécrétion de progestérone à $445 \pm 43 \mathrm{j}$ à un poids de $418 \pm 36 \mathrm{~kg}$. Certains facteurs environnementaux ayant une influence sur l'âge à la puberté ont été identifiés : l'année et la période de naissance, l'âge de la mère et la naissance gémellaire. L'action de certains de ces facteurs est liée a un effet sur la croissance de la génisse. Une fois les données ajustées pour ces facteurs de milieu, une relation phénotypique modérée mais favorable persiste entre vitesse de croissance des génisses et âge à la puberté. (C) Elsevier/Inra)
\end{abstract}

puberté / astrus / progestérone / croissance / génisse à viande

* Correspondence and reprints

Tel.: (33) 1346521 93; fax: (33) 1346522 10; marie-madeleine.mialon@dga.jouy.inra.fr 


\section{INTRODUCTION}

Reproductive efficiency is an important component of beef cattle production. An early puberty allows an early first mating and reduces the unproductive lifetime. Timing of puberty is highly variable and is dependent on a number of both genetic and environmental factors $[17,18]$.

Puberty characteristics show considerable variability between breeds of different biological types: breeds with higher lean growth and larger mature size (specialised continental beef breeds) tend to reach puberty at a later age than breeds that were selected for milk production $[6,7,11]$. Large variabilities are, however, observed within particular breeds and a number of experiments have been conducted to try to understand their origin.

This variability has been studied in relation to two well-defined factors that influence the timing of puberty onset: nutrition and season of birth [28]. The specific effect of nutrition has been evaluated in different experiments where heifers were given high vs. low energy diets after weaning $[8,10$, $29,36]$. The results clearly show that heifers fed low energy diets take longer to reach puberty than heifers under adequate nutrition management. The effect of the season of birth has been studied but could hardly be separated from the indirect effect of growth $[2,3,9,10,35]$.

Even when these identified environmental effects are taken into account, age at puberty remains highly variable among heifers due to both genetic and unidentified environmental effects. The accuracy of the method for determining age at puberty contributes to this unidentified environmental variability. Most studies are based on the observation of oestrous behaviour using different detection techniques, except in Gauthier et al. [9] where the proportion of cycled heifers was estimated using a progesterone test according to the method proposed by Thimonier [33].
The aim of the present work was to describe the variability and principally, the genetic variability of puberty establishment in Charolais heifers reared in a controlled environment. Two operative techniques of puberty appreciation were used, 10 months per year for 7 years: the observation of oestrus and the progesterone test. Neither of these two techniques were designed to simply estimate the mere age at puberty, since measure errors may exist, but rather to allow the study of a large number of females, so that enough information could be obtained in order to analyse the sources of (phenotypic and genetic) variation among heifers. In this first article, the influence of some environmental factors on age at puberty is reported and the phenotypic variability of this puberty age is described in relationship with growth performance of the heifers.

\section{MATERIAL AND METHODS}

\subsection{Data source}

This study includes observations made on 351 Charolais heifers born in the Inra experimental herd (Bourges, Centre of France) over a 7-year period (1988-1994). The calving periods were from mid-January to mid-April. After weaning at 32 weeks of age, the heifers were reared in free stall barns and fed a roughage ration (hay or grass silage, concentrate complements) providing approximately $4.5 \mathrm{UFL} \cdot \mathrm{d}^{-1}$ (UFL: feed unit for lactating or rearing females) and $430 \mathrm{PDI} \cdot \mathrm{d}^{-1}$ (PDI: protein truly digested in the intestine), allowing an average growth rate of approximately $600 \mathrm{~g} / \mathrm{d}$ during their 1 st postweaning year. The peripubertal period was studied and heifers were bred at 2 years of age.

Between 10 and 20 months of age, all heifers were divided into groups of 16 , and checked twice daily for oestrous activity (in the morning and in the afternoon) with the aid of vasectomized young bulls. Heifers were considered to be in oestrus if they stood to be mounted. During the same period, two blood samples were collected every month at 10-day intervals from the caudal vein according to the method proposed by Thimonier [33]. This experimental design involved alternating intervals of 10 or 20 days. Proges- 
terone concentrations were measured by radioimmunoassay according to the procedure described by Terqui and Thimonier [32].

To assess puberty, the information provided by oestrus detection and progesterone tests was used in two different ways. First, at a given age (e.g. at 15 months) the pubertal status of each heifer was characterised by one of three categorical variables: either the heifer had already been observed for oestrus, already had a positive progesterone test, or it exhibited none, one or both events. Second, the dates of the first observed oestrus and the first positive progesterone test were recorded and the corresponding ages were calculated. These two ages were normally distributed.

The weights at the first observed oestrus and at the first positive progesterone test were calculated by interpolation from the two nearest weights using these ages. Furthermore, since oestrus detection was maintained for 10 to 20 months, each heifer could be observed several times and the duration of the oestrous cycle could be measured between two successive oestruses for a more detailed assessment of pubertal status. In our analysis, an oestrous cycle lasting from 17 to 25 days was considered as a normal one, as in most studies [21].

The heifers were weighed every month for growth assessment. Birth, weaning and 12-month weights were recorded. The growth rates until 12 months of age were divided into periods of average daily gains from birth to weaning, and from weaning to 12 months of age. Body condition was scored on a 6 -point scale $(0=$ leanest, 5 = fattest; [1]) at 12 months of age. At 15 months of age, the heifers were measured for hip height, trochanter width and pelvic opening.

\subsection{Analysis of data}

In order to study the variability of the different traits related to puberty, we first tested the effects of some identified environmental factors using either a generalised linear model for categorical variables (GENMOD of SAS [26]) or a general linear model for continuous variables (GLM of SAS [25]). The identified sources of environmental variation were: 7 years of birth (1988-1994), six periods of birth (end of January, four 2-week periods in February and March, and early April), three ages of the dams (3-4, 5-6 and 7+ years) and two types of birth (single or twin). The male twin sisters were not included in this puberty study. The effect of twinning on both categorical traits was tested separately due to its low incidence $(3.1 \%$ of the heifers were born as twins).

After adjustment for these identified environmental factors, the relationships between the residual variability of both puberty-related ages and residual variability of the other heifer traits were examined. Correlations were calculated between ages and live weight, growth rate, size and pelvic measurements, and body condition scores. This description of relationships between both puberty-related ages and performance traits was completed by multiple regressions in order to calculate the relative incidence of growth traits on both ages.

\section{RESULTS}

\subsection{Description of events occurring around puberty}

\subsubsection{First observed oestrus and positive progesterone test}

Between 10 and 20 months of age, $98 \%$ of the heifers were observed in oestrus, at a mean age of $426 \pm 42$ days ( $95 \%$ had a positive progesterone test at $445 \pm 43$ days). The corresponding weights were $406 \pm$ $38 \mathrm{~kg}$ at the first observed oestrus and $418 \pm$ $36 \mathrm{~kg}$ at the first positive progesterone test (table I).

At 15 months of age, $72 \%$ of the heifers were observed in oestrus versus $11 \%$ at 12 months ( $56 \%$ had a positive progesterone test vs. $5 \%$, respectively) (table I).

\subsubsection{Oestrous cycles}

During this 10-month period, the number of oestrous behaviours observed per female varied greatly among females. Eight percent of the heifers with less than two oestrous behaviours did not succeed in establishing a single oestrous cycle.

For the 324 females exhibiting two oestruses or more, the distribution of the duration of the oestrous cycle is given in figure $l$ ( $n=1581$ cycles). This figure shows essentially three zones of density. 


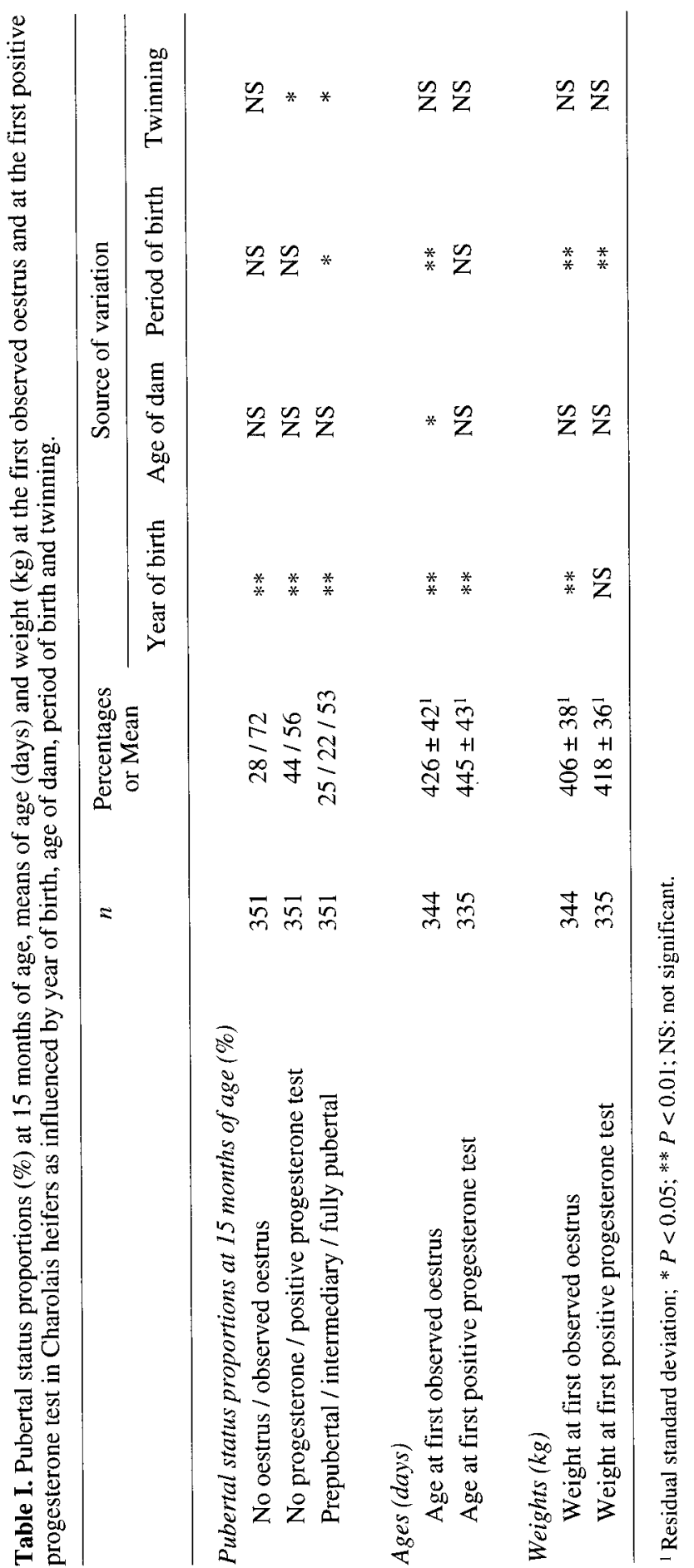


The zone with the greatest number of cycles (55\% of the cycles) is around 19-21 days and includes the cycles considered as normal. Under 17 days, a zone of short cycles with equally distributed durations from 4 to 16 days represents $20 \%$ of the observed cycles. The remaining $25 \%$ of the cycles are longer than 25 days, with a majority situated between 34 and 48 days. This duration clearly corresponds to approximately the double of the normal duration.

\subsubsection{Chronology of the establishment of reproductive activity at puberty}

At a given age, the proportion of the heifers that was observed in oestrus was always higher than the proportion of heifers with a positive progesterone test (figure 2). In $70 \%$ of the heifers, the first oestrus was observed before the first progesterone test and in $30 \%$ of the heifers, afterwards. Consequently, the heifers were, on the average,

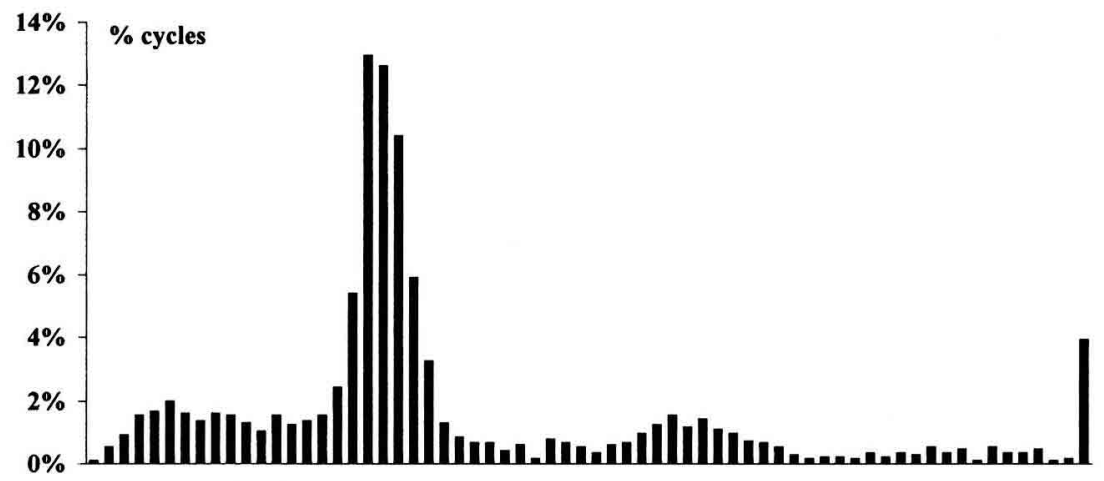

$\begin{array}{lllllllllllllllllllllllll}1 & 4 & 7 & 10 & 13 & 16 & 19 & 22 & 25 & 28 & 31 & 34 & 37 & 40 & 43 & 46 & 49 & 52 & 55 & 58 & 61 & 64 & \mathbf{5} & 65\end{array}$

duration of cycles (days)

Figure 1. Distribution of oestrous cycle duration for Charolais heifers between 10 and 20 months of age $(n=1581$ cycles $)$.

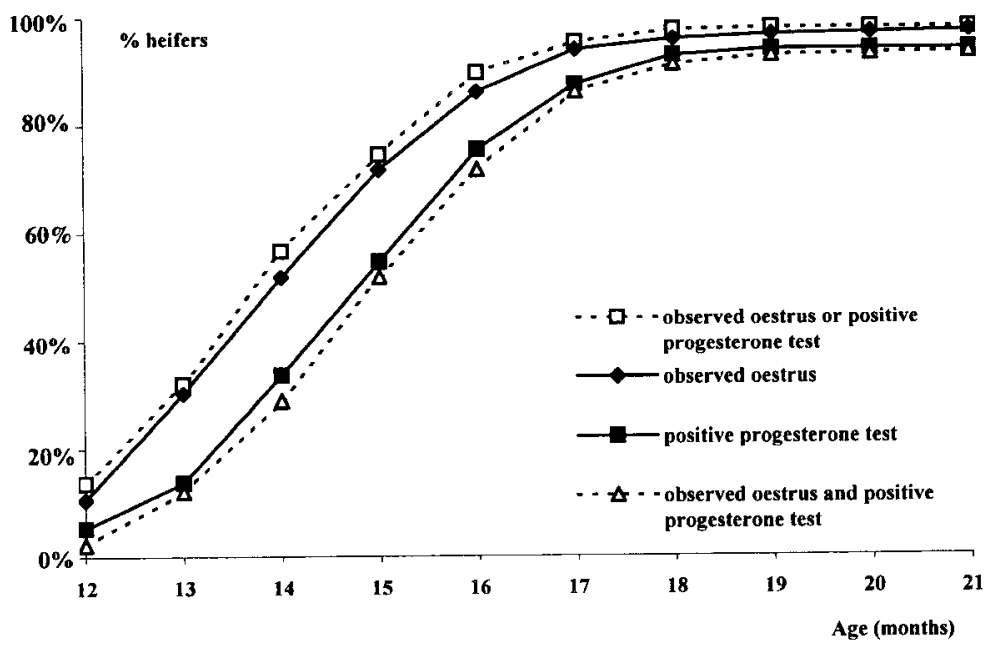

Figure 2. Evolution of the proportion of heifers with either an observed oestrus, a positive progesterone test, or both events. 
19 days younger at the first observed oestrus than at the first positive progesterone test (426 vs. 445 days, respectively).

At each given age, three groups of females can be distinguished. A first group with no observed oestrus and no positive progesterone test was considered as prepubertal heifers. A second group with both events was called fully pubertal females. The third group was an intermediate group of heifers undergoing the onset of puberty. In this latter group, only one of both puberty-related events already occurred. At 15 months of age, $25 \%$ of the heifers $(n=86)$ were prepubertal, $53 \%(n=187)$ fully pubertal and $22 \%(n=78)$ were in the intermediate group (table I). In this intermediate group, ten heifers had a positive progesterone test without oestrus observation and 68 were observed in oestrus without a positive progesterone test. This latter proportion can be partly explained by the blood sampling rhythm, twice monthly, while oestruses were detected daily. The first positive test was expected to be obtained after an average 2 weeks after the corresponding first ovulation, when considering the sampling rhythm and the above results on cycle duration $(21 \%$ of first oestrous cycles were of short duration).

\subsection{Source of variation}

The effects of different identified sources of variation are summarised in table $I$.

\subsubsection{Year}

The year of birth significantly influenced all categorical or continuous variables related to puberty and growth traits. It appeared that this year effect on pubertyrelated traits was closely linked to its effect on growth. The 12-month-old heifers were heavier during the years 1990, 1991, 1992 $(+45 \mathrm{~kg})$ than those of the years 1988, 1989, $1993(P<0.01)$. In addition, when comparing 15 -month-old heifers during these same two periods of years, there was a larger proportion of pubertal heifers (77 vs. $17 \%$ ) and a lower proportion of prepubertal heifers (9 vs. $48 \%$, respectively). The ages at the first observed oestrus and first positive progesterone test were, respectively, 34 and 55 days younger during these years with a higher growth rate while the weights at the first observed oestrus and first positive progesterone test were not significantly different: 12 and $1 \mathrm{~kg}$ heavier.

This effect of year is clearly illustrated in figure $3 a$, where the proportion of heifers with positive progesterone tests is plotted against age for those years with a sufficient number of tested heifers (years 1988 and 1994 are not plotted). About $60 \%$ of the heifers born in 1990 had a positive progesterone test at 13.5 months, while those heifers born in 1989 or 1993 reached that $60 \%$ proportion only at 15.5 or 16.5 months of age, respectively. These differences between years were largely reduced when that proportion was plotted against the weight of the heifers (figure $3 b$ ). Whatever the year, $60 \%$ of the heifers had already had a positive progesterone test when their weight was between 420 and $440 \mathrm{~kg}$.

\subsubsection{Age of dam}

Dam age had a significant effect only on the age at the first observed oestrus: daughters from older cows ( 7 years and over) tended to be older. We noticed that daughters from these older cows were lighter at 12 months of age than other heifers, although the differences were not significant. Therefore, the effect of dam age on the establishment of puberty was related to an effect on heifer growth.

\subsubsection{Period of birth}

Period of birth significantly influenced the pubertal status at 15 months of age and the age at the first observed oestrus. Heifers born early in the calving season (end of January and February) were older at the first 

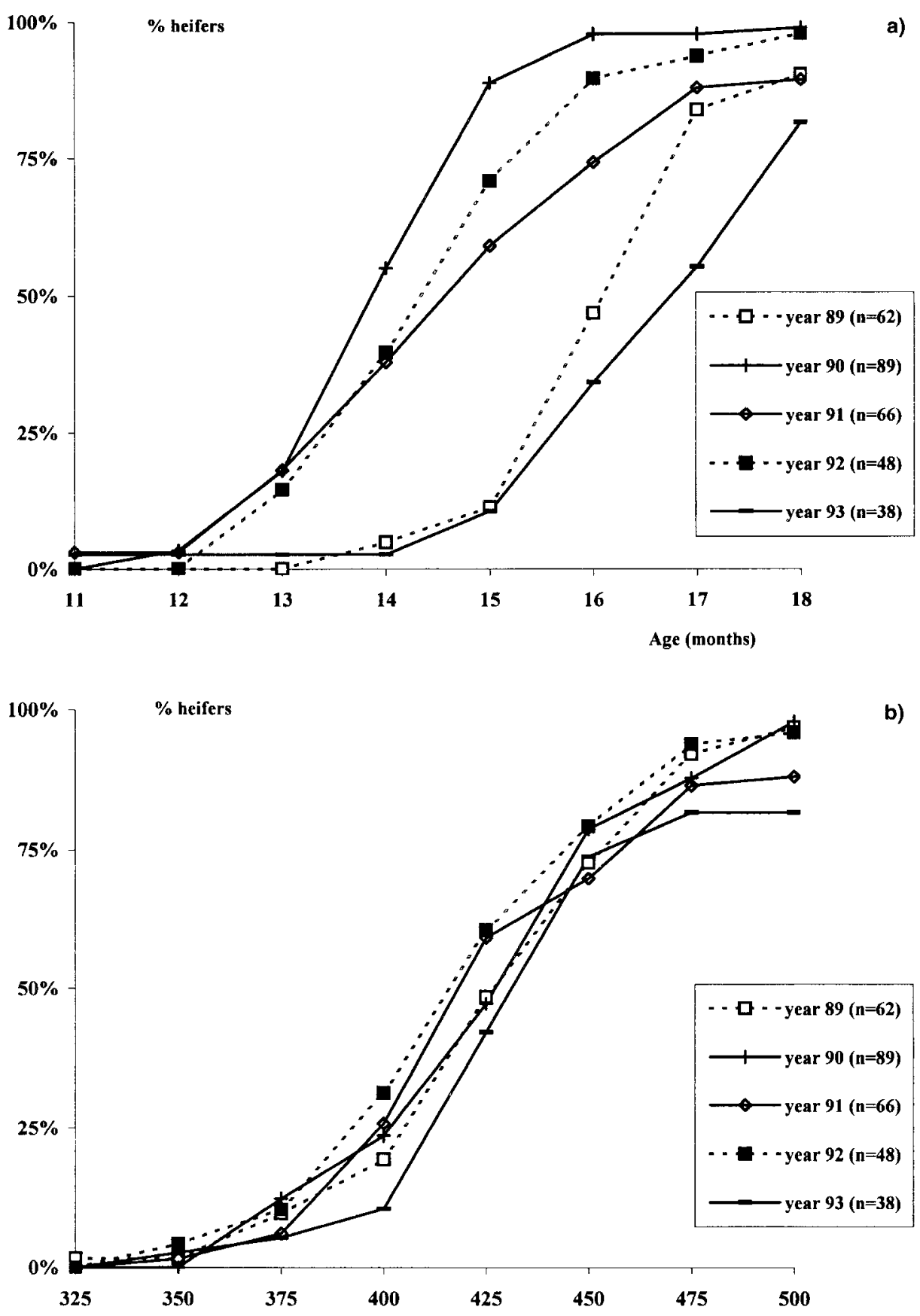

Figure 3. a) Evolution of the proportion of heifers with a positive progesterone test as a function of age (year effects). b) Evolution of the proportion of heifers with a positive progesterone test as a function of weight (year effects). 
observed oestrus ( +23 days) than heifers born late (March and early April). At 15 months of age, a higher proportion were prepubertal $(+15 \%)$ and a lower proportion were fully pubertal $(-14 \%)$. This effect of the period of birth was not mediated by an effect on growth rate since these early born heifers tended to be heavier ( $+8 \mathrm{~kg}$, not significant [NS]) at 12 months of age, and these heifers were significantly heavier at the first observed oestrus $(+29 \mathrm{~kg})$ and first positive progesterone test $(+17 \mathrm{~kg})$.

\subsubsection{Twinning}

Due to its low incidence, the twinning effect was not statistically significant $(P>0.05)$ for most of the puberty-related traits although its magnitude was relatively important. At 15 months of age, there were significantly more prepubertal and less fully pubertal females among twins than singleborn heifers. Twin-born heifers were 12 days older and $8 \mathrm{~kg}$ lighter at their first oestrous behaviour ( 15 days older and $6 \mathrm{~kg}$ lighter at the first positive progesterone test) than single-born heifers. This effect was clearly mediated by its effect on growth rate since these twin-born heifers were also $25 \mathrm{~kg}$ lighter at 12 months of age than single-born heifers.

\subsection{Relationship between puberty and others traits}

\subsubsection{Relationship between puberty age-related traits}

The five puberty age-related traits, three categorical and two continuous, were clearly interdependent (table II). The correlation between ages at the first observed oestrus and first positive progesterone test was $r=+0.64$. These two ages were evidently related to the pubertal status at 15 months of age: heifers, fully pubertal at 15 months of age, were 83 and 84 days younger on the average when they were first observed in oestrus and had their first positive progesterone test than prepubertal heifers.
These puberty age-related traits were all positively correlated with weights at the first observed oestrus and at the first positive progesterone test: the older, the heavier the heifers at both puberty events.

\subsubsection{Relationship between puberty- related traits and growth traits}

When considering the relationship between pubertal status at 15 months of age and growth rate of heifers, it appeared that differences in the pubertal status were related to significant differences in growth rate both before and after weaning (table III). The correlation between the ages and growth rate confirmed this relationship (correlation coefficients between -0.15 and -0.31 ): the heifers with a higher growth rate before and after weaning tended to be younger at puberty.

Growth from birth to 12 months of age was inserted in a multiple regression. The growth was divided into three periods: birth weight, average daily gain from birth to weaning and from weaning to 12 months of age. For age at the first observed oestrus, the effects of growth rate from birth to weaning and from weaning to 12 months were equivalent with partial $\mathrm{R}^{2}$ of 1.8 and $1.3 \%$, respectively. For age at the first positive progesterone test, the rate of growth during the preweaning period tended to have the greatest influence (partial $\mathrm{R}^{2}$ of $6.2 \%$ ). Growth differences, however, only accounted for $4 \%$ of the total variation in age at the first observed oestrus and $10.4 \%$ of the total variation in age at the first positive progesterone test.

\subsubsection{Relationship between puberty- related traits and other traits}

\subsubsection{Body condition score at 12 months}

The comparison of the body condition score of heifers of different pubertal status showed that heifers already experiencing one of the events related to puberty were in a better body condition at 12 months of age 

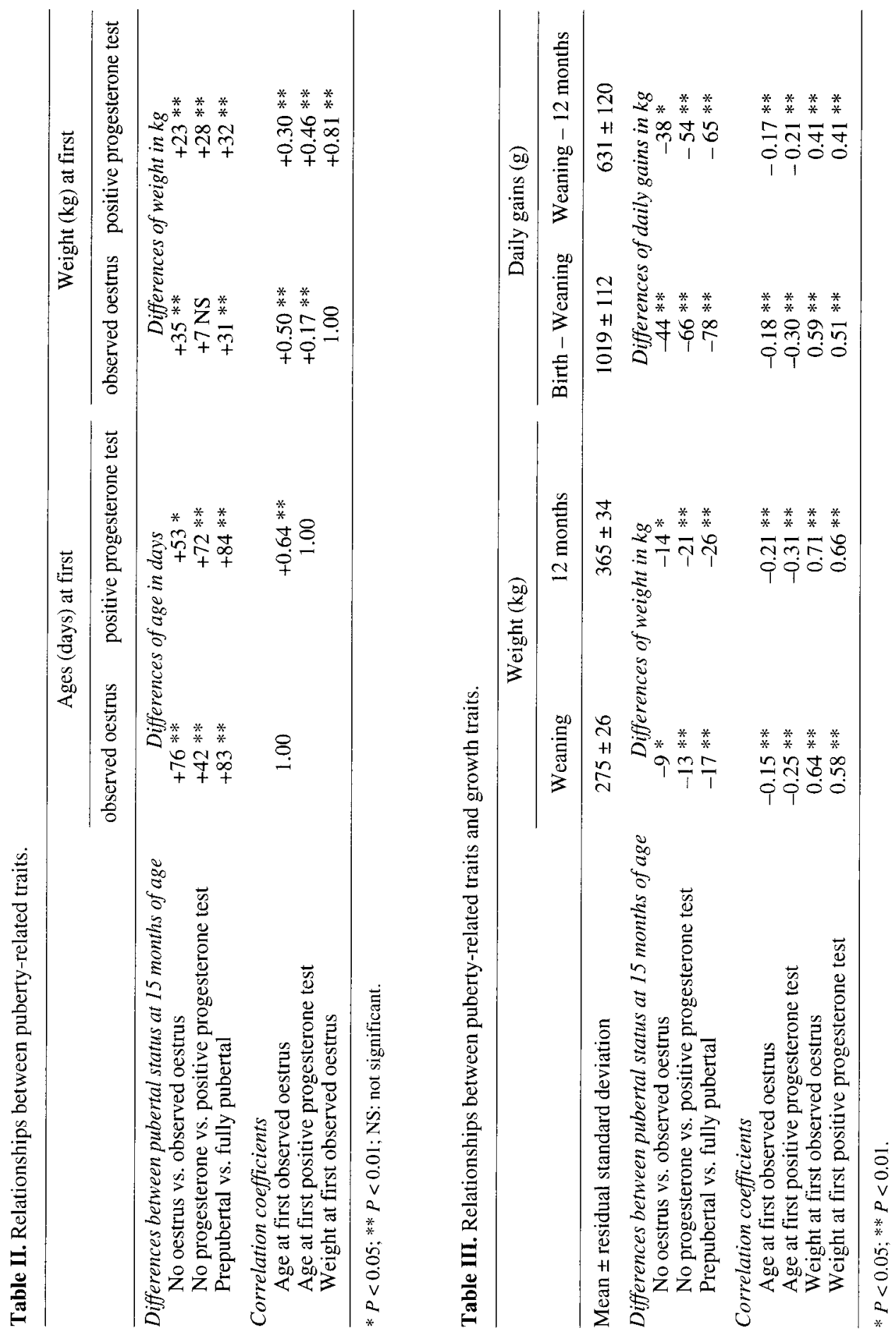
(table IV). The correlations also showed that heifers with higher body condition scores at 12 months of age tended to be slightly younger when they first experienced an oestrus or a positive progesterone test. However, when the relationship was estimated at a constant 12 months weight, the body condition score actually appeared to have very little influence on the different ages. The introduction of the body condition score with growth rate in the previous multiple regression did not increase the proportion of total variation explained by the model. In conclusion, in our experiment, the body condition score at 12 months of age was not related in an important way to pubertyrelated traits.

\subsubsection{Morphological characters}

The two characteristics, hip height and trochanter width, poorly discriminated heifers of different pubertal status: these differences were at most $1.7 \%$ of the mean (table IV). The pelvic opening, however, differed more for groups of heifers. For example, the pelvic opening of 15 -monthold prepubertal heifers was $8 \%$ smaller than that of fully pubertal heifers. The correlation between size at 15 months of age and puberty-related traits were negative; the taller and/or wider the heifers, the younger they tended to be at puberty. However, the magnitude of these coefficients was reduced and was no longer significant when calculated at a constant 12-month weight.

\section{DISCUSSION}

Little information is available in the literature about age at puberty in Charolais heifers. Under French breeding conditions, the published results show a large range of age at puberty $[13,22,24]$. The last estimates given by Sapa et al. [24] were: age at first oestrus, 399 days and $43 \%$ of females observed in oestrus at 15 months of age. Our results are included within this range with a mean age at the first observed oestrus of 14 months at about $60 \%$ of the adult weight. At 15 months of age, $75 \%$ of the heifers were fully pubertal or were undergoing the puberty onset process.

From our observations, the first oestrus occurred after the first positive progesterone test in one-third of the heifers. Such observations were described by Morrow [19], who reported that the first ovulation was accompanied by silent oestrus in $74 \%$ of the Holstein heifers. In our experiment, some short oestrous behaviours, as already described [5, 31, 34], might have occurred during the night between the last observation period in the afternoon and the first one on the next morning, and as a result the corresponding ovulation could be considered to be silent. Such a high proportion of silent first ovulation might be due not only to the limitations of our experimental design (duration and frequency of the observation periods, as compared to the recommendations of Van Vliet and Van Eerdenburg [34]) but also to biological reality.

On the contrary, for $32 \%$ of the heifers the first oestrus was logically observed before the first positive progesterone test but the interval between the two events appeared too long to be explained by the limits of the experimental design. Some of these oestruses might be considered as nonpubertal oestruses defined as oestrous behaviours not related to ovulation in heifers $[20,23]$. Under the conditions used in our study, this phenomenon was more common early in the season (for $42 \%$ of the first oestruses observed before 1 April) at young ages (for $43 \%$ of the first oestruses observed before 400 days of age) and at light weights (for $42 \%$ of the first oestruses observed for weights less than $400 \mathrm{~kg}$ ).

The aim of our experiment was to control an important number of heifers in order to describe the variability at puberty establishment. In some cases, due to some restrictions of our experimental design, the first observations of oestrus or the positive progesterone test may not be the first occur- 


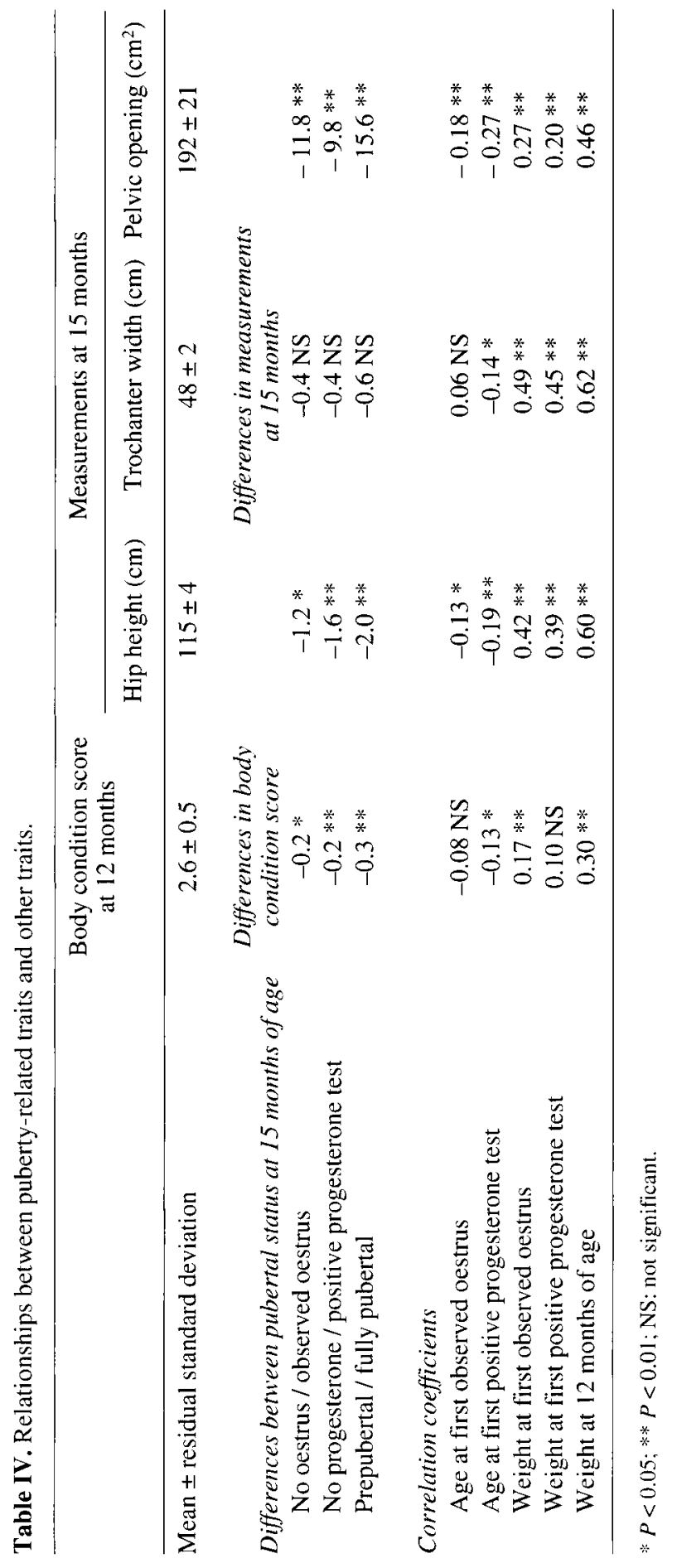


ring events. In order to take this into account, two types of information were analysed: categorical and continuous traits. For analysing relationship of puberty traits with continuous traits like growth rate, the analysis of pubertal status (categorical variables) was less risky but also less informative than analysis of ages (continuous variables), with the reserves linked to the experimental design. These two types of analyses always led to the same conclusions when the influence of environmental factors or the relationships with growth rate were studied. This strengthened the use of the two ages in performing elaborate studies and reporting conclusions.

Some environmental factors had effects on puberty-related traits. For some of them, like year of birth, age of dam and twinning, the effect was mediated by an effect on heifer growth rate. The description of the effects of year and of twinning on yearling weight and puberty ages underlined the interdependence between puberty and growth characteristic. A difference of $45 \mathrm{~kg}$ in weight at 12 months between years was associated with a difference of 55 days in age at the first positive progesterone test. These year effects were certainly mediated by the nutritional status linked to forage quality, climatic variations, etc. The period of birth also influenced the age at puberty but independently of growth rate. Heifers born early in the year showed their first oestrous behaviours at an older age than those born later. Nutrition and type of housing were the same whatever the period of birth, since heifers were kept in free stall barns all year round without a grazing period. Therefore, the effect of the period of birth was probably not an effect of management factors. Period of birth probably acts through the photoperiod and perhaps through the temperature $[14,27]$. Otherwise, the social interaction with other females in oestrus and the presence of the bull twice a day might increasingly influence the behaviour of young heifers [34,
37]. This phenomenon might add to the season effect.

We studied the relationship between growth rate and puberty ages when data were adjusted for environmental factor effects. The growth rate from birth to 1 year of age had a significant influence on pubertal status at 15 months of age and was related to age at puberty. Prepubertal heifers had a significantly lower growth rate during the pre- and postweaning periods than fully pubertal heifers. Most authors show a favourable relationship between a high growth rate before weaning and an early puberty $[2,3,35,36]$. For the postweaning period, the relationship is less clear $[2,3,4$, $9,12,16,30,35,36]$. In our experiment, we observed that pre- and postweaning daily gains had an equivalent effect on age at the first observed oestrus of heifers. These growth rates during pre- and postweaning periods (1 019 and $631, \mathrm{~g} \cdot \mathrm{d}^{-1}$, respectively) were similar to the means observed on farms in the Charolais area in France: 1029 and $677 \mathrm{~g} \cdot \mathrm{d}^{-1}$, respectively [15]. The correlations between growth rate and pubertyrelated traits were, however, relatively low in our experiment since they corresponded to observations obtained on heifers all managed in the same environment. A difference of $45 \mathrm{~kg}$ (1.5 standard deviation) in weight at 12 months of age was associated with a difference of 19 days in age at the first positive progesterone test. If the environment had been less favourable for growth and therefore involved a larger variability in growth rate, the relationship between growth and ages might have been more marked.

\section{CONCLUSION}

The results of this study showed a large individual variability in the age of puberty establishment of Charolais heifers managed under similar conditions, and allowed to quantify the relationship between this variability and growth rate variability. Further analyses are needed, first to estimate which 
part of this individual variability is attributable to additive effects of genes and to unidentified environmental effects, and second, to estimate the sign and the magnitude of genetic and environmental correlations between growth rate and pubertyrelated traits.

In our experiment, heifers were bred to calve at 3 years of age. Our results suggest that it is possible to decrease the breeding age of these beef heifers to approximately 21 months of age instead of the current norm in French breeding conditions of 24 months. Given our data concerning the average age for the onset of puberty, it appeared, however, that breeding them earlier (e.g. at 14-15 months) might jeopardise the results of this first mating season, since only $53 \%$ of the heifers were fully pubertal at 15 months of age. A further reduction of age at first breeding may need, therefore, an improvement of age at puberty by management and/or by selection if possible.

\section{ACKNOWLEDGEMENTS}

The authors wish to thank the staff at the Inra experimental herd of Galle for help with oestrus detection, blood sampling and data collection, A. Neau for writing the relevant computer programmes used in data collection, D. André (Inra, Laboratory of Hormonal Assays) for performing progesterone assays and W. Brand-Williams for English revision of the manuscript.

\section{REFERENCES}

[1] Agabriel J., Giraud J.M., Petit M., Détermination et utilisation de la note d'état d'engraissement en élevage allaitant, Bull. Tech. CRZV Theix Inra 66 (1986) 43-50.

[2] Arije G.F., Wiltbank J.N., Age and weight at puberty in Hereford heifers, J. Anim. Sci. 33 (1971) $401-406$.

[3] Arije G.F., Wiltbank J.N., Prediction of age and weight at puberty in beef heifers, J. Anim. Sci. 38 (1974) 803-810.

[4] Baker J.F., Stewart T.S., Long C.R., Cartwright T.C., Multiple regression and principal components analysis of puberty and growth in cattle, J. Anim. Sci. 66 (1988) 2147-2158.
[5] Chupin D., Petit M., Mauleon P., Maîtrise de l'oestrus et synchronisation des cycles sexuels chez les bovins, Bull. Tech. Inform. Minist. Agric. 257 (1971) 163-174.

[6] Cundiff L.V., Gregory K.E., Koch R.M., Dickerson G.E., Genetic diversity among cattle breeds and its use to increase beef production efficiency in a temperate environment, Proc. $3^{\text {rd }}$ World Congr. on Genet. Appl. to Livestock Prod., Lincoln, NE, USA, 9 (1986) 271-282.

[7] Dow J.S. Jr., Moore J.D., Bailey C.M., Foote W.D., Onset of puberty in heifers of diverse beef breeds and crosses, J. Anim. Sci. 55 (1982) 1041-1047.

[8] Ferrell C.L., Effects of postweaning rate of gain on onset of puberty and productive performance of heifers of different breeds, J. Anim. Sci. 55 (1982) 1272-1283.

[9] Gauthier D., Nerot F., Garel J.P., Petit M., Étude de la puberté chez la génisse Salers. Influence de certains paramètres de l'environnement, Bull. Tech. CRZV Theix Inra 64 (1986) 55-58.

[10] Grass J.A., Hansen P.J., Rutledge J.J., Hauser E.R., Genotype X environmental interactions on reproductive traits of bovine females. I. Age at puberty as influenced by breed, breed of sire, dietary regimen and season, J. Anim. Sci. 55 (1982) 1441-1457.

[11] Gregory K.E., Lunstra D.D., Cundiff L.V., Koch R.M., Breed effects and heterosis in advanced generations of composite populations for puberty and scrotal traits of beef cattle, J. Anim. Sci. 69 ( 1991 ) 2795-2807.

[12] Gregory K.E., Cundiff L.V., Koch R.M., Genetic and phenotypic (co)variances for production traits of female populations of purebred and composite beef cattle, J. Anim. Sci. 73 (1995) 2235-2242.

[13] Grenet N., Les facteurs influençant la reproduction des troupeaux allaitants, Annuel pour l'éleveur de bovins (1982) 41-54.

[14] Hansen P.J., Kamwanja L.A., Hauser E.R., Photoperiod influences age at puberty of heifers, J. Anim. Sci. 57 (1983) 985-992.

[15] Institut de l'Elevage, Résultats du contrôle de performances bovins allaitants - France - campagne 97, CR n $2725,1998,79 \mathrm{p}$.

[16] Laster D.B., Glimp H.A., Gregory K.E., Age and weight at puberty and conception in different breeds and breed-crosses of beef heifers, J. Anim. Sci. 34 (1972) 1031-1036.

[17] Martin L.C., Brinks J.S., Bourdon R.M., Cundiff L.V., Genetic effects on beef heifer puberty and subsequent reproduction, J. Anim. Sci. 70 (1992) 4006-4017.

[18] Moran C., Quirke J.F., Roche J.F., Puberty in heifers: a review, Anim. Reprod. Sci. 18 (1989) 167-182.

[19] Morrow D.A., Estrous behavior and ovarian activity in prepuberal and postpuberal dairy heifers, J. Dairy Sci. 52 (1968) 224-227. 
[20] Nelsen T.C., Short R.E., Phelps D.A., Staigmiller R.B., Nonpuberal estrus and mature cow influences on growth and puberty in heifers, J. Anim. Sci. 61 (1985) 470-473.

[21] Peters A.R., Ball P.J.H., The ovarian cycle, in: Peters A.R., Ball P.H.J. (Eds.), Reproduction in Cattle, Butterworths \& Co., Kent, 1987, pp. 20-39.

[22] Petit M., Vêlage précoce dans les troupeaux de vaches allaitantes, Bull. Techn. C.R.Z.V. Theix Inra 22 (1975) 5-16.

[23] Rutter L.M., Randel R.D., Nonpuberal estrus in beef heifers, J. Anim. Sci. 63 (1986) 1049-1053.

[24] Sapa J., Menissier F., Renand G., Liboriussen T., Courteix S., Duclaud P.J., Variabilité génétique de la croissance et de la fertilité de génisses de races à viande françaises spécialisées, 41 th EAAP, Toulouse, France, July 1990.

[25] SAS, The GLM Procedure, SAS User's Guide: Statistics, Version 5, SAS Institute Inc., Cary, NC, USA, 1985, pp. 432-506.

[26] SAS, The GENMOD Procedure, Release 6.09, SAS Technical Report P-243, SAS/STAT Software, SAS Institute Inc., Cary, NC, USA, 1993, $88 \mathrm{p}$.

[27] Schillo K.K., Hansen P.J., Kamwanja L.A., Dierschke D.J., Hauser E.R., Influence of season on sexual development in heifers: age at puberty as related to growth and serum concentrations of gonadotropins, prolactin, thyroxine and progesterone, Biol. Reprod. 28 (1983) 329-341.

[28] Schillo K.K., Hall J.B., Hileman S.M., Effects of nutrition and season on the onset of puberty in the beef heifer, J. Anim. Sci. 70 (1992) 3994 4005.

[29] Short R.E., Bellows R.A., Relationships among weight gains, age at puberty and reproductive performance in heifers, J. Anim. Sci. 32 (1971) $127-131$

[30] Smith B.A., Brinks J.S., Richardson G.V., Estimation of genetic parameters among reproductive and growth traits in yearling heifers, J. Anim. Sci. 67 (1989) 2886-2891.

[31] Stevenson J.S., Smith M.W., Jaeger J.R., Corah L.R., LeFever D.G., Detection of estrus by visual observation and radiotelemetry in peripubertal, estrus-synchronised beef heifers, J. Anim. Sci. 74 (1996) 729-735.

[32] Terqui M., Thimonier J., Nouvelle méthode radioimmunologique rapide pour l'estimation du niveau de progestérone plasmatique. Application pour le diagnostic précoce de la gestation chez la brebis et la chèvre, CR Acad. Sci. Paris 279 (1974) 1109-1112.

[33] Thimonier J., L'activité ovarienne chez les bovins. Moyens d'étude et facteurs de variations, Ann. Med. Vet. 122 (1978) 81-92.

[34] Van Vliet J.H., Van Eerdenburg F.J.C.M., Sexual activities and oestrus detection in lactating Holstein cows, Appl. Anim. Behav, Sci, 50 (1996) 57-69.

[35] Werre J.F., Brinks J.S., Relationships of age at puberty with growth and subsequent productivity in beef heifers, Proc. West. Sec. Am. Soc. Anim. Sci. 37 (1986) 300-303.

[36] Wiltbank J.N., Gregory K.E., Swiger L.A., Ingalls J.E., Rothlisberger J.A., Koch R.M., Effects of heterosis on age and weight at puberty in beef heifers, J. Anim. Sci. 25 (1966) 744 751.

[37] Wright I.A., Rhind S.M., Smith A.J., Whyte T.K., Female-female influences on the duration of the postpartum anoestrous period in beef cows, Anim. Prod. 59 (1994) 49-53. 